\title{
Safety of Autologous Umbilical Cord Blood Therapy for Acquired Sensorineural Hearing Loss in Children
}

\author{
Linda S. Baumgartner ${ }^{1}$, Ernest Moore ${ }^{2}$, David Shook ${ }^{3}$, Steven Messina ${ }^{4}$, Mary Clare Day ${ }^{5}$, \\ Jennifer Green ${ }^{3}$, Rajesh Nandy ${ }^{6}$, Michael Seidman ${ }^{7}$, and James E. Baumgartner ${ }^{3,8,9}$ \\ ${ }^{1}$ Little HEARoes \& Clarke Schools for Hearing and Speech, Orlando, FL, USA \\ ${ }^{2}$ Department of Audiology and Speech-Language Pathology, University of North Texas, Denton, TA, USA \\ ${ }^{3}$ Florida Hospital for Children, Orlando, FL, USA \\ ${ }^{4}$ Florida Radiology Institute, Orlando, FL, USA \\ ${ }^{5}$ Little HEARoes, LLC, Winston Salem, NC, USA \\ ${ }^{6}$ Department of Biostatistics, School of Public Health, University of North Texas, Fort Worth, TA, USA \\ ${ }^{7}$ Florida Hospital Celebration, Celebration, FL, USA \\ ${ }^{8}$ Shriner's Hospital for Children, Houston, TA, USA \\ ${ }^{9}$ Department of Neurosurgery, University of Central Florida College of Medicine, Orlando, FL, USA
}

Received March 15, 2018

Revised May 20, 2018

Accepted June 18, 2018
Background and Objectives: Sensorineural hearing loss (SNHL) in children is associated with neurocognitive morbidity. The cause of SNHL is a loss of hair cells in the organ of Corti. There are currently no reparative treatments for SNHL. Numerous studies suggest that cord blood mononuclear cells (human umbilical cord blood, hUCB) allow at least partial restoration of SNHL by enabling repair of a damaged organ of Corti. Our objective is to determine if hUCB is a safe treatment for moderate to severe acquired SNHL in children. Subjects and Methods: Eleven children aged 6 months to 6 years with moderate to severe acquired SNHL were treated with intravenous autologous hUCB. The cell dose ranged from 8 to 30 million cells/kg body weight. Safety was assessed by measuring systemic hemodynamics during hUCB infusion. Infusion-related toxicity was evaluated by measuring neurologic, hepatic, renal and pulmonary function before and after infusion. Auditory function, auditory verbal language assessments and MRI with diffusion tensor imaging (DTI) were obtained before and af ter treatment. Results: All patients survived, and there were no adverse events. No infusionrelated changes in hemodynamics occurred. No infusion-related toxicity was recorded. Five subjects experienced a reduction in auditory brainstem response (ABR) thresholds. Four of those 5 subjects also experienced an improvement in cochlear nerve latencies. Comparison of MRI with DTI sequences obtained before and after treatment revealed increased fractional anisotropy in the primary auditory cortex in three of five subjects with reduced ABR thresholds. Statistically significant $(p<0.05)$ reductions in $A B R$ thresholds were identified. Conclusions: TIntravenous hUCB is feasible and safe in children with SNHL.

J Audiol Otol 2018;22(4):209-222

KEY WORDS: Human umbilical cord blood · Mesenchymal stem cells · Mononuclear fraction · Sensorineural hearing loss · Auditory brainstem response . Otoacoustic emission · Diffusion tensor imaging · Fractional anisotropy.

\section{Introduction}

Sensorineural hearing loss (SNHL) is a permanent sensory disorder affecting more than 270 million people worldwide.
The incidence of SNHL increases from 2/1000 in newborns to $5 / 1000$ in children aged $3-17$ years to $33 \%$ of adults aged $65-74$ years to $50 \%$ of those greater than 85 years of age [1,2]. Existing treatments (hearing aids and cochlear implants) are

This is an Open Access article distributed under the terms of the Creative Commons Attribution Non-Commercial License (https:/creativecommons. org/licenses/by-nc/4.0/) which permits unrestricted non-commercial use, distribution, and reproduction in any medium, provided the original work is properly cited. 
designed to improve the symptoms of SNHL by augmenting the damaged organ of Corti. These treatments fail to reverse the underlying pathology, which is the loss of sensory inner hair cells in the organ of Corti. Inner, outer and structural hair cells are necessary for hearing and ultimately transform sound waves into electrical impulses transmitted to the brain. The loss of hair cells reduces auditory input to the brain, and hearing impairment develops with sufficient hair cell loss. In mammals, the organ of Corti is post-mitotic at birth, and no spontaneous hair cell regeneration occurs thereafter.

Among infants and children with SNHL, 23\% to 50\% of SNHL is the result of a genetic mutation (Connexin 26 mutation, Waardenburg syndrome, Usher syndrome, mitochondrial disorders, etc.) [2-5]. The remaining infants and children have acquired SNHL, which is most commonly attributed to prematurity, infection (in utero or post-delivery) and exposure to noise or oto-toxic drugs.

In preclinical and clinical studies, the intravascular delivery of mesenchymal progenitor cells in acute neuro-pathologic insults (stroke, traumatic brain injury, spinal cord injury, etc.) have shown significant promise [6-12]. Experimentally deafened mice and guinea pigs experienced cochlear repair after cord blood mononuclear cells (human umbilical cord blood, hUCB)-derived cell transplantation [13,14]. Following myeloablation and hUCB transplantation, patients with mucopolysaccharidosis have experienced an improvement in SNHL [15]. The most common cell populations used in these trials include bone marrow mononuclear fraction and hUCB mononuclear fraction. The bone marrow treatments require a bone marrow harvest. The hUCB treatment utilizes a mixed cell population rich in progenitor cells that are collected and cryopreserved at birth. Minimal cell processing is required, and an ample cell number is usually available for use in a pediatric population. Using an autologous cell product, we avoid the potential for graft vs host disease, and cell rejection and blood-borne disease transfer can be avoided. Acquired SNHL is a neuro-pathologic insult to the organ of Corti that may respond to hUCB treatment.

This study presents the results of a phase 1 clinical trial to evaluate the intravenous administration of hUCB mononuclear fraction in infants and children with acquired SNHL. Our protocol was designed to evaluate the feasibility, logistics and safety of autologous hUCB treatment in this patient population. We also sought to acquire limited dose/response data, auditory function, language development and structural [MRI with diffusion tensor imaging (DTI) sequences] outcome data for future trial planning.

\section{Subjects and Methods}

This study was conducted under Federal Investigational New Drug (IND) Application \#15354 and was approved by the Florida Hospital Committee for the Protection of Human Subjects (IRBnet \#434269) and Florida Hospital Office of Research Administration.

\section{Patient enrollment}

Following IND and IRB approval, a recruitment email was sent to families who had banked their children's cord blood with Cord Blood Registry® (CBR ${ }^{\circledR}$, San Bruno, CA, USA). The email invited parents of children with SNHL to contact the research team and the Florida Hospital for Children. After contact was initiated, an informed consent form was sent to the subject's parents/guardians. Once the parents/guardians had reviewed, signed and returned the informed consent, a telephone interview was performed with a member of the research team. Following the interview, parents/guardians who wished to participate forwarded their child's medical records to Orlando for review. If the subject met the inclusion and exclusion criteria (Table 1), human leukocyte antigen (HLA) typing was performed on the potential study subject and then compared to the results from a sample received from $\mathrm{CBR} \otimes$ for identity confirmation. If the HLA typing matched, arrangements were made for the subject's hUCB unit to be sent to the Florida Hospital Cell Processing Lab where it remained stored in liquid nitrogen until the date of infusion. A treatment date was then arranged with the subject's parents/caregivers, and travel plans were confirmed.

Patients could only be enrolled longitudinally after review of their initial post-treatment course by an independent data safety management board. All data were audited by an external clinical monitor. Fig. 1 is a graphic timeline of the patient enrollment and treatment experience.

\section{Patient management}

Parental informed consent was re-obtained in person prior to obtaining a history, conducting a physical exam and performing baseline audiological and neurological assessments. Auditory verbal speech language assessment, audiology testing [auditory brainstem response (ABR), otoacoustic emission testing (OAE), tympanometry and audiogram], screening laboratory and X-ray testing were also performed at the baseline visit.

On the day of infusion, the patient was admitted to the Florida Hospital for Children. Under general anesthesia, a 3 tesla MRI of the brain with DTI sequences was obtained. If the nonsedated ABR was inadequate, an ABR was obtained under anesthesia. The patient was allowed to recover from anesthe- 
sia and was then admitted to the bone marrow transplant unit of the Florida Hospital for Children for continued recovery and monitoring.

\section{Cord blood infusion}

On the day of the infusion, the hUCB unit was thawed and washed in the Florida Hospital Cell Processing Laboratory.

Table 1. Study inclusion and exclusion criteria

Inclusion criteria for patients with acquired SNHL who were screened for the trial

1) Evidence of SNHL:

a. Moderate to profound in degree (40-90 decibels)

b. Unilateral or bilateral configuration

c. Symmetrical or asymmetrical configuration

d. Sudden or progressive in presentation

2) Hearing loss must be considered acquired

a. History of in utero infection or

b. Negative genetic screening

3) Fitted for hearing aids no later than 6 months following detection of hearing loss

4) Aged 6 weeks to 6 years at the time of infusion, with less than 18 months of hearing loss at the time of infusion

5) Ability of the child and caregiver to travel to Orlando and stay for at least 4 days for infusion

6) Ability of the child and caregiver to return to Orlando for follow-up visits

Exclusion criteria for patients with acquired SNHL who were screened for the trial

1) Inability to obtain pertinent medical records

2) Known history of:

a. Recently treated infection $<2$ weeks before infusion.

b. Renal disease (serum creatinine $>1.5 \mathrm{mg} / \mathrm{dL}$ ).

c. Hepatic disease (SGPT >150 U/L and/or T. bilirubin $>1.3 \mathrm{mg} / \mathrm{dL}$ ).

d. Malignancy

e. Immunosuppression (WBC <3000)

f. HIV

g. Hepatits B or C

h. Evidence of an extensive stroke (>100 mL lesion)

i. Pneumonia or chronic lung disease requiring oxygen

j. Genetic hearing loss

3) hUBC sample contamination

4) Banked cord blood cells totaling $<6$ million cells per kilogram subject weight.

5) Participation in a concurrent study

6) Unwillingness or inability to stay in Orlando for 4 days following cord blood infusion.

7) Unwillingness or inability to return for scheduled follow-up visits and testing.

8) Presence of a cochlear implant device

9) Evidence of active maternal infection during pregnancy

a. Hepatitis $A$

b. Hepatitis $B$

c. Hepatitis $C$

d. HIV 1

e. HIV 2

f. Human T-lymphotropic virus (HTLV) 1

g. HTLV 2

h. Syphilis

i. CMV is NOT among the exclusion criteria

10) Conductive hearing loss

11) Documented recurrent middle ear infections (>5/year)

12) Otitis media on the pre-infusion physical examination

13) SNHL that is mild

14) Greater than 18 months of hearing loss at the time of infusion

SNHL: sensorineural hearing loss, SGPT: serum glutamate-pyruvic transaminase, WBC: white blood cells, CMV: cytomegalovirus, HIV: human immunodeficiency virus 


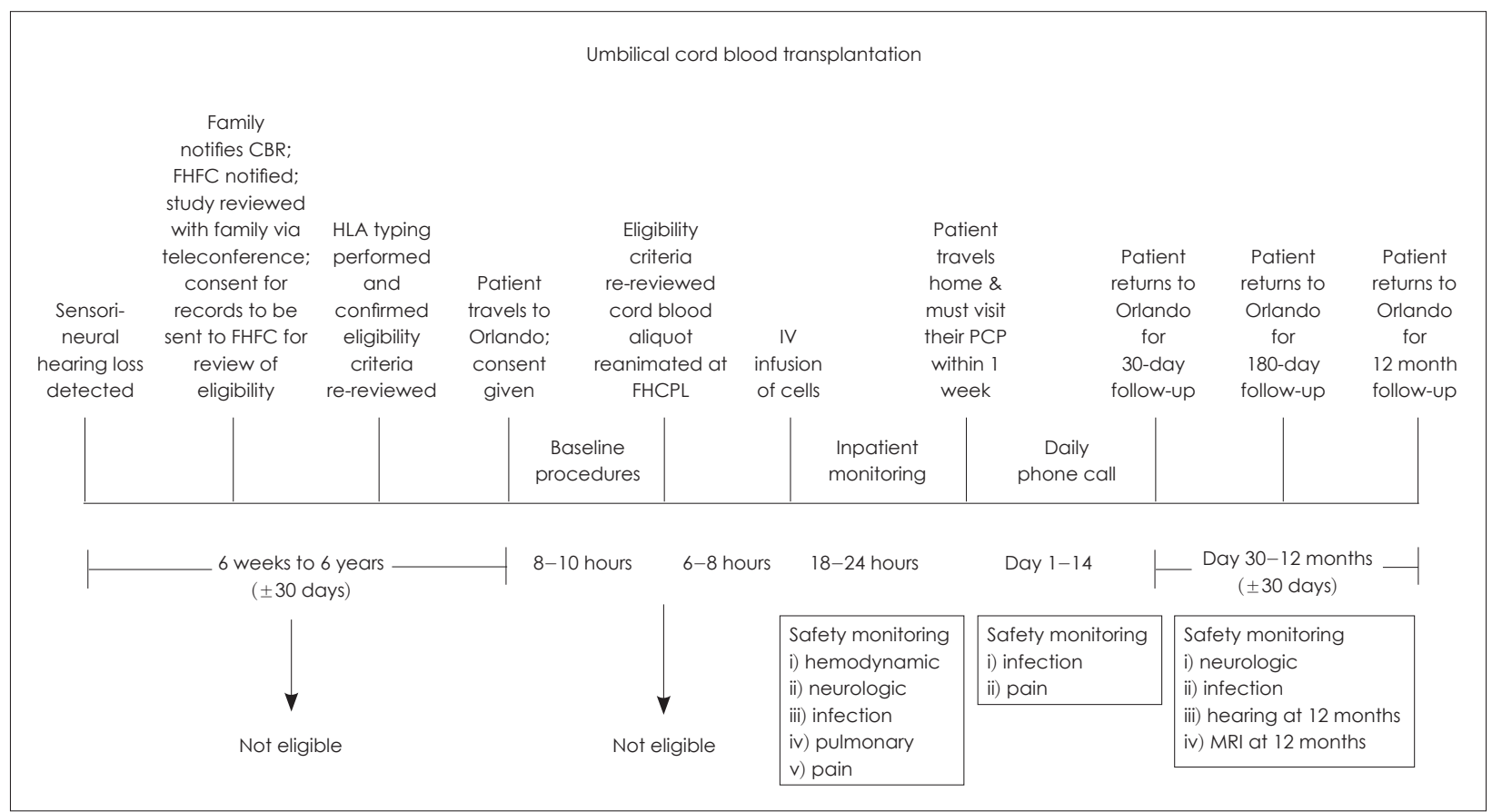

Fig. 1. Graphic representation of the patient enrollment and treatment timeline. CBR: Cord Blood Registry, FHFC: Florida Hospital for Children, FHCPL: Florida Hospital Cell Processing Lab, HLA: human leukocyte antigen, PCP: primary care physician.

When the cord blood preparation was completed and the cord blood unit was determined to have met laboratory release criteria, it was transported to the bone marrow transplant unit. After baseline vital signs were obtained, the subjects were pre-medicated with diphenhydramine (Benadryl, Johnson \& Johnson, New Brunswick, NJ, USA) and methylprednisolone (Solu-Medrol, Pfizer, New York, NY, USA). Thirty minutes after premedication, the hUCB unit was infused intravenously under the supervision of a hematologist (DS) experienced in bone marrow transplantation. Infusion was gravity-based. Vital signs were recorded every 15 minutes during the infusion, as well as for 4 hours following infusion. The patient was monitored overnight in the bone marrow transplant unit, and baseline laboratory values as well as a chest X-ray were rechecked in the morning following infusions. If the repeat lab values and chest films were within expected limits, the patient was discharged from the hospital. The parents/caregivers were provided with a digital thermometer and were contacted daily to follow the patient's status for 14 days following discharge. The patient's parents/caregivers were instructed to follow-up with their primary care physician on returning home.

\section{Follow-up visits}

The subjects and their parents returned for follow-up at 1 , 6 and 12 months post infusion. At the 1-month, 6-month and 12-month follow-up visits, physical and neurological examinations were performed as well as tympanometry, OAE and
ABR testing. Speech-language pathology evaluations were performed during the 6 and 12-month follow-up visits. At the 12-month follow-up visits, an MRI with DTI sequences was obtained.

\section{Monitoring for infusion-related toxicity}

\section{Pulmonary}

Pulmonary function was assessed by continuous $\mathrm{PaO}_{2}$ measurement during anesthesia for the MRI/ABR, and while the patient was hospitalized in the bone marrow transplant unit for hUCB infusion. $\mathrm{PaO}_{2}$ was also recorded at each follow-up visit. Standard chest X-rays were obtained on the day of hUCB infusion, the day after hUCB infusion and at each follow-up visit.

\section{Renal}

Serum creatinine and blood urea nitrogen were obtained as a measure of renal function before hUCB infusion, the day after hUCB and at each follow-up visit.

\section{Neurological}

A complete neurological examination was performed one day prior to and one day following hUCB infusion and at each subsequent follow-up visit. 


\section{Hematologic}

A complete blood count with differential and platelet count was obtained one day before hUCB infusion, the day after hUCB infusion and at each follow-up visit.

\section{Hepatic}

The hepatic transaminases [aspartate transaminase (AST) and alanine transaminase (ALT)] were measured the day before hUCB infusion, the day after hUCB infusion and at each follow-up visit as an index of hepatic injury/toxicity.

\section{Longitudinal functional and language outcome testing}

$\mathrm{ABR}, \mathrm{OAE}$, audiogram and tympanometry were obtained on the day before or if necessary on the day of the hUCB infusion and at each subsequent follow-up visit. Audiologic data were reviewed at the time of collection by a senior audiologist (EM). Changes of greater than a $\pm 5 \mathrm{~dB}$ ABR threshold were considered significant. Changes greater than \pm 0.5 milliseconds in peak 5 of CN VIII conduction latency were considered significant. Age-appropriate speech-language pathology testing was obtained by an experienced auditory verbal speechlanguage pathologist (LB) on the day before hUCB infusion and at the 6- and 12-month follow-up visits, using the Preschool Language Scale, 4th edition [16].

\section{Statistical methods}

Statistical analysis was performed by a biostatistician $(\mathrm{RN})$ experienced in analyzing audiologic data. SAS 9.4 (Statistical Analysis System, Cary, NC, USA) was used to perform all the analyses. Statistical significance tests were performed for the effect of hUCB infusion on ABR thresholds and CN VIII peak 5 latencies using the change scores at the three follow-ups after the intervention. To assess the efficacy of the treatment, within-subject analysis of variance (ANOVA) was performed for the change scores at the 1-month, 6- month and 12-month follow-ups. For the ABR thresholds, 5 different measurements at various frequencies [click $2,000 \mathrm{~Hz}$, tone burst (TB) at 500, 1,000, 2,000 and 4,000 Hz] were recorded for each ear, resulting in a total of 10 measurements for each subject at each follow-up time point. For latency, 6 different measurements at various frequencies were recorded for each ear, resulting in a total of 12 measurement for each subject at each follow-up time point. Apart from investigating the overall treatment effect, we also studied the direction of change in the outcome for individual subjects. Due to the very small sample size as well as some missing data within the pool, the overall power is expected to be low. Consequently, statistical significance for treatment may not be achieved for all of the outcomes using ANOVA, even if the treatment is effective.
However, even in the absence of statistical significance, if the change in the relevant outcome is in the expected direction in most cases, it can be considered to be an evidence towards efficacy of the treatment. Under the null hypothesis of no treatment effect, there is a $50 \%$ chance for the change in each outcome to be in the desired direction. The probability of observing a specific number of change scores in the desired direction can be easily calculated using a binomial distribution with probability 0.5 . Let $\mathrm{k}$ be the number of observed change scores in the desired direction. If the probability of observing at least $\mathrm{k}$ change scores in the desired direction using binomial distribution is less than 0.05 under the null hypothesis, the result will be considered statistically significant and the treatment be deemed effective.

\section{3-T MRI with DTI sequences}

Imaging protocols for brain MRI with DTI were performed using 3.0-T MR (Verio; Siemens Medical, Erlangen, Germany) with a 16-channel head coil. The DTI sequence was as follows: time to echo $84 \mathrm{~ms}$, time to relaxation $10,000 \mathrm{~ms}, 250 \times$ $250 \mathrm{~mm}$ slice with $4 \mathrm{~mm}$ spacing, $0 \mathrm{~mm}$ gap, matrix $128 \times 100$, 38 directions 25 , maximum $B$ value $1,000 \mathrm{~s} / \mathrm{mm}^{2}$. Images were obtained on the day of hUCB infusion and at the 12-month follow-up visit. DTI imaging was processed with DynaSuite (InVivo; Gainesville, FL, USA). Maximum and mean fractional anisotropy (FA) were recorded for bilateral inferior colliculi, medial geniculate, auditory radiations, and white matter of Heschl's gyrus for each patient at baseline and 1-year followup MRI using region of interest (ROI) analysis. All images were reviewed in a blinded fashion by an experienced neuroradiologist $(\mathrm{SM})$.

\section{Results}

\section{Demographics}

The clinical demographics of the patients enrolled in the study are summarized in Table 2. Subject enrollment began in November 2013, and follow-up evaluations were completed in February 2017. Subjects were enrolled longitudinally, allowing for a complete one-month safety review of each patient before enrolling the next subject.

\section{Cord blood infusion hemodynamics}

There were no significant hemodynamic changes during or after the hUCB infusion, nor was there a notable change in hemoglobin/hematocrit levels after the procedure.

\section{Cell dose characterization}

The total nucleated cells (TNC) administered, age at treat- 
Table 2. Study subject demographics

\begin{tabular}{|c|c|c|c|c|c|}
\hline Subject \# & Sex/degree of hearing loss & $\begin{array}{l}\text { Age at cord } \\
\text { blood Rx }\end{array}$ & $\begin{array}{l}\text { Duration of } \mathrm{HL} \\
\text { prior to infusion }\end{array}$ & $\begin{array}{l}\text { Time from identification } \\
\text { to amplification }\end{array}$ & $\begin{array}{c}\text { Failed } \\
\text { newborn } \\
\text { screening }\end{array}$ \\
\hline 1 & $\mathrm{~F} /$ mild to moderate & 5 years 7 months & 1 year 3 months & $\begin{array}{l}1 \text { month, hearing aids all waking } \\
\text { hours }\end{array}$ & - \\
\hline 2 & $\mathrm{~F} /$ moderate & 12 months 27 days & 11 months & $\begin{array}{l}1 \text { month, hearing aids all waking } \\
\text { hours }\end{array}$ & + \\
\hline 3 & $\mathrm{~F} /$ mild to moderate & 6 years 11 months & 1 year 3 months & $\begin{array}{l}1 \text { month, hearing aids all waking } \\
\text { hours }\end{array}$ & - \\
\hline 4 & $\mathrm{~F} /$ severe to profound & 9 months & 1 month & $\begin{array}{l}7 \text { months, hearing aids maximum } \\
4 \text { hours/day }\end{array}$ & + \\
\hline 5 & $\mathrm{M} /$ mild to moderate & 2 years 10 months & 2 years 3 months & $\begin{array}{l}18 \text { months, hearing aids less } \\
\text { than all waking hours }\end{array}$ & - \\
\hline 6 & F/mixed conductive and mild & 1 year 9 months & 1 year 1 month & $\begin{array}{l}8 \text { months, hearing aids all } \\
\text { waking hours }\end{array}$ & + \\
\hline 7 & $\mathrm{~F} /$ moderate to severe right ear & 5 months & 5 months & 4 months & - \\
\hline 8 & M/unilateral profound & 2 years 10 months & 2 years 7 months & 1 year 11 months (Baha) & + \\
\hline 9 & F/severe to profound & 3 years 6 months & 3 years 5 months & 8 months & + \\
\hline 10 & $\mathrm{M} /$ moderate right, severe left & 14 months & 10 months & $\begin{array}{l}4 \text { months, hearing aids all wak- } \\
\text { ing hours }\end{array}$ & - \\
\hline 11 & M/bilateral severe to profound & 11 months & 1 month & $\begin{array}{l}1 \text { month, hearing aids all waking } \\
\text { hours }\end{array}$ & $\begin{array}{l}\text {-(33-week } \\
\text { preemie) }\end{array}$ \\
\hline
\end{tabular}

Five subjects who passed newborn screening and later developed hearing loss are classified as "acquired SNHL." The six subjects who failed newborn screening are classified as "congenital SNHL." Nine subjects' genetic screenings were negative for genetic SNHL markers. The remaining two subjects experienced CMV infection in utero. SNHL: sensorineural hearing loss, HL: hearing loss

Table 3. Study subject cell dose and response

\begin{tabular}{clcc}
\hline Subject \# & $\begin{array}{c}\text { Age at hUCB } \\
\text { treatment }\end{array}$ & Cell dose/kg & $\begin{array}{c}\text { Response: } \\
\text { ABR/latency }\end{array}$ \\
\hline 1 & 5 years 7 months & $8 \times 10^{6}$ & $-/-$ \\
2 & 1 year 1 month & $8 \times 10^{6}$ & $-/-$ \\
3 & 6 years 11 months & $20 \times 10^{6}$ & $-/-$ \\
4 & 9 months & $21 \times 10^{6}$ & $+/-$ \\
5 & 2 years 8 months & $15 \times 10^{6}$ & $+/+$ \\
6 & 1 year 9 months & $30 \times 10^{6}$ & $+/+$ \\
7 & 6 months & $20 \times 10^{6}$ & $-/-$ \\
8 & 1 year 10 months & $28 \times 10^{6}$ & $+/+$ \\
9 & 3 years 7 months & $28 \times 10^{6}$ & $+/+$ \\
10 & 1 year 2 months & $20 \times 10^{6}$ & $-/-$ \\
11 & 10 months & $10 \times 10^{6}$ & $-/-$ \\
\hline
\end{tabular}

Changes of greater than $\pm 5 \mathrm{~dB} A B R$ threshold were considered significant. Changes greater than \pm 0.5 milliseconds in $\mathrm{CN}$ VIII peak 5 conduction latency were considered significant. Exact treatment responses for responding subjects (ABR threshold and $\mathrm{CN}$ VIII peak 5 latencies) at baseline and at each followup measurement are summarized in Table 4-7. hUCB: human umbilical cord blood, ABR: auditory brainstem response

ment and response to treatment are summarized in Table 3. Clinical improvements were only found following hUCB doses greater than $15 \times 10^{6} \mathrm{TNC} / \mathrm{kg}$.

\section{Infusion-related toxicity}

\section{Pulmonary}

There were no significant changes in $\mathrm{PaO}_{2}$ between the pre-hUCB infusion, post-hUCB infusion or follow-up $\mathrm{PaO}_{2}$ measurements. No changes were detected on chest X-rays obtained before or after hUCB infusion or at any follow-up visits.

Renal

The serum creatinine and blood urea nitrogen levels remained stable and within normal limits before and after hUCB infusion as well as at all follow-up visits.

Hepatic

The ALT and AST transiently and mildly increased following hUCB infusion in 2/11 patients (subjects 5 and 10). Both patients were observed as inpatients for an additional 24 hours post infusion. On repeat lab testing, the ALT and AST had either normalized or were decreasing toward normal. The changes were typical of those observed following stem cell infusion for other conditions. The AST and ALT were within normal limits on all follow-up measurements. 


\section{Neurological}

The neurological examinations remained stable for all subjects before and after hUCB infusion and at all follow-up visits.

\section{Longitudinal functional and speech-language outcomes}

ABR threshold improvement was observed in five subjects. Four of these five subjects also experienced improvements in CN VIII peak 5 latencies. Representative pre- and post-treatment audiograms, as well as corresponding ABR tracings, are shown in Fig. 2. Data for the four subjects with both the ABR threshold and CN VIII peak 5 latency improvement are summarized in Table 4-7. When improvements in ABR threshold or latency occurred, they were evident on one-month follow-up testing and were durable throughout the study follow-up (Table 4-7). Subject 4, who experienced a reduction in ABR threshold without an improvement in CN VIII peak 5 latency, was the only child to experience worsening language scores (Table 8). In this instance, the parents revealed poor adherence to recommended hearing aid use and speechlanguage therapy. No 6- or 12-month follow-up data were obtained for Subject 11, whose parents chose to proceed with bilateral cochlear implantation after he did not experience any improvements at the one-month follow up testing. While speculative, reductions in ABR thresholds may represent replacement of hair cells or repair of the organ of Corti [17]. Improved CN VIII peak 5 latencies may represent repair of the spiral ganglion.

Regardless of response to hUCB treatment, 10/11 subjects' standard scores on the Preschool Language Scale 4th edition remained stable or improved (Table 9). One study participant (Subject 7) dropped out of the trial before 6- or 12-month follow-up testing could be completed. Subject 4, who had poor compliance with recommended hearing aid use and speech therapy, experienced a decline in standard language scores despite an improvement in ABR threshold measures. Subject 4 reinforces the necessity of adequate amplification and ther-
Fig. 2. Representative audiograms (top) and ABR recordings at 4,000 $\mathrm{Hz}$ (below) of subject 5 before (left) and after (right) hUCB treatment. The improvements on the behavioral testing (audiogram) match the changes found on the ABR recordings (physiologic). hUCB: human umbilical cord blood, ABR: auditory brainstem response.

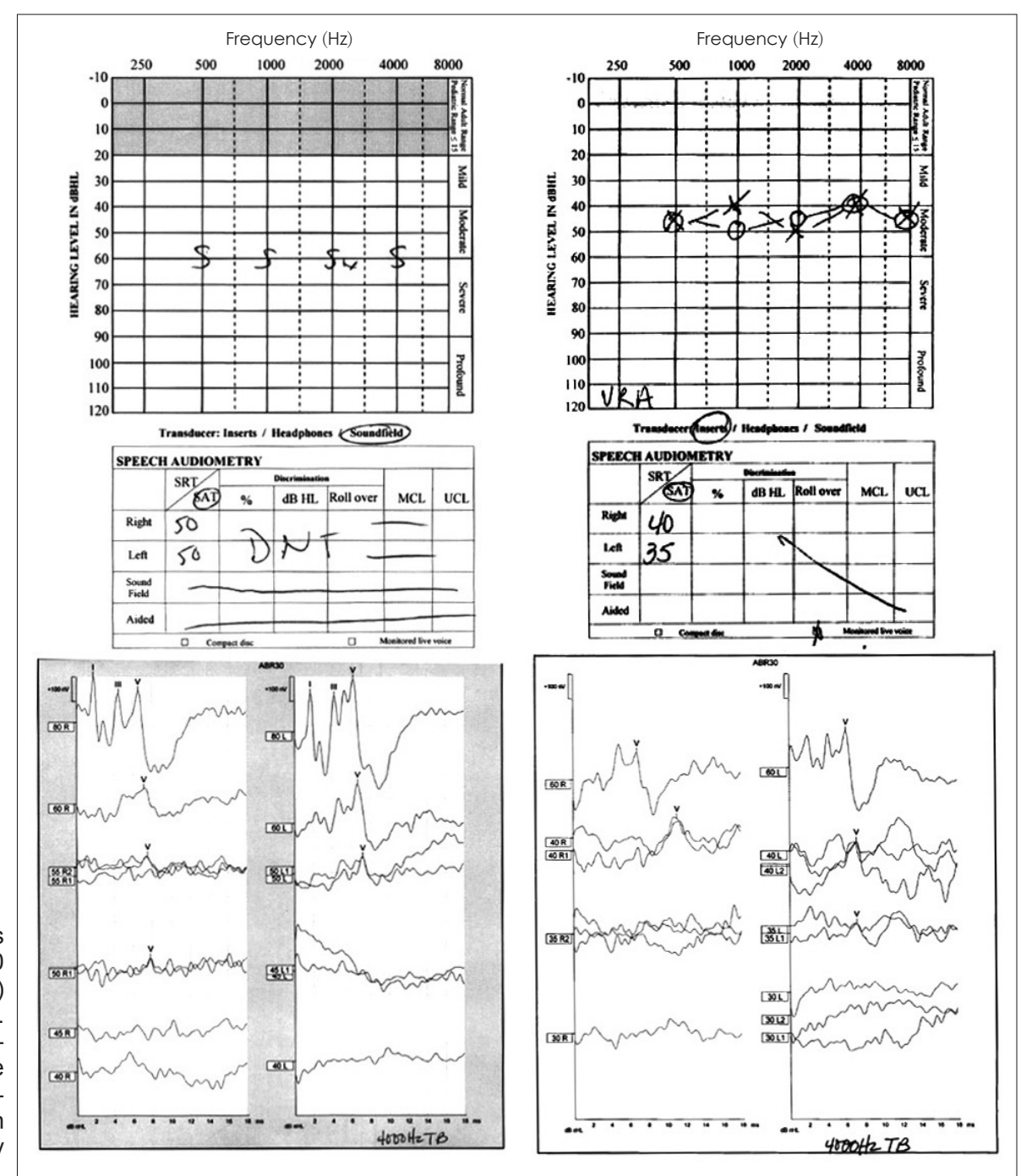


Table 4. ABR and CN VIII wave 5 latencies for responding subject 9

\begin{tabular}{|c|c|c|c|c|c|c|}
\hline \multicolumn{7}{|c|}{ A. ABR sensitivity: $A B R A C$ and $A B R$ TB at $500,1,000,2,000$, and $4,000 \mathrm{~Hz}$ (tympanometry A/A at pre, 1-, 6-, and 12-month follow-up) } \\
\hline Test/Ear & Frequency $(\mathrm{Hz})$ & $\begin{array}{l}\text { Baseline } \\
\text { (dB) }\end{array}$ & $\begin{array}{c}1 \text { month } \\
\text { after } \operatorname{Rx}(\mathrm{dB})\end{array}$ & $\begin{array}{c}6 \text { months } \\
\text { after Rx }(\mathrm{dB})\end{array}$ & $\begin{array}{c}1 \text { year } \\
\text { after } \operatorname{Rx}(\mathrm{dB})\end{array}$ & $\begin{array}{c}\text { Change from baseline }(\mathrm{dB}) \\
1 / 6 / 12 \text { months }\end{array}$ \\
\hline ABR/AC/left & 2,000 & 85 & 75 & 80 & 80 & $-10 /-5 /-5$ \\
\hline ABR/AC/right & 2,000 & 95 & 80 & 70 & 70 & $-15 /-25 /-25$ \\
\hline ABR/TB/left & 500 & 85 & 85 & 80 & 80 & $0 /-5 /-5$ \\
\hline ABR/TB/right & 500 & 90 & 70 & 60 & 60 & $-20 /-30 /-30$ \\
\hline ABR/TB/left & 1,000 & 85 & 75 & 80 & 70 & $-10 /-5 /-15$ \\
\hline ABR/TB/right & 1,000 & 80 & 70 & 60 & 65 & $-10 /-20 /-15$ \\
\hline ABR/TB/left & 2,000 & 90 & 80 & 85 & 85 & $-10 /-5 /-5$ \\
\hline $\mathrm{ABR} / \mathrm{TB} /$ right & 2,000 & 80 & 80 & 85 & 80 & $0 / 5 / 0$ \\
\hline ABR/TB/left & 4,000 & 100 & 95 & 100 & 95 & $-5 / 0 /-5$ \\
\hline $\mathrm{ABR} / \mathrm{TB} / \mathrm{right}$ & 4,000 & 90 & 90 & 90 & 90 & $0 / 0 / 0$ \\
\hline
\end{tabular}

B. Latency: $A B R$ wave $V$ latency ( $\mathrm{ms}$ )-the speed/efficiency of signal transmission along the cochlear nerve (tympanometry $A / A$ at pre, 1-, 6-, and 12-month follow-up)

\begin{tabular}{lcccccc}
\hline \multicolumn{1}{c}{ Test/Ear } & Frequency $(\mathrm{Hz})$ & $\begin{array}{c}\text { Baseline } \\
\text { latency }\end{array}$ & $\begin{array}{c}1 \text { month } \\
\text { after Rx }\end{array}$ & $\begin{array}{c}6 \text { months } \\
\text { after Rx }\end{array}$ & $\begin{array}{c}12 \text { months } \\
\text { after Rx }\end{array}$ & $\begin{array}{c}\text { Change from baseline } \\
1 / 6 / 12 \mathrm{months}\end{array}$ \\
\hline ABR/AC/Left & 2,000 at $95 \mathrm{~dB}$ & 10.13 & 7.53 & Not collected & Not collected & $-0.26 / \mathrm{NA} / \mathrm{NA}$ \\
ABR/AC/Right & 2,000 at $95 \mathrm{~dB}$ & 7.47 & 6.47 & 6.53 & Not collected & $-1.0 /-0.94 / \mathrm{NA}$ \\
ABR/TB/Left & 500 at $90 \mathrm{~dB}$ & 13.33 & 10.00 & 11.33 & 10.00 & $-3.3 /-2.0 /-3.3$ \\
ABR/TB/Right & 500 at $90 \mathrm{~dB}$ & 9.53 & 9.13 & 9.67 & 9.73 & $-0.4 /+0.14 /+0.2$ \\
ABR/TB/Left & 1,000 at $90 \mathrm{~dB}$ & 12.00 & 11.60 & 10.67 & 9.67 & $-0.4 /-1.33 /-2.33$ \\
ABR/TB/Right & 1,000 at $90 \mathrm{~dB}$ & 9.53 & 9.47 & 9.00 & 9.60 & $-0.06 /-0.53 /+0.07$ \\
ABR/TB/Left & 2,000 at $90 \mathrm{~dB}$ & 9.40 & 8.27 & 9.87 & 8.20 & $-1.13 /+0.47 /-1.20$ \\
ABR/TB/Right & 2,000 at $90 \mathrm{~dB}$ & 8.53 & 7.80 & 7.33 & 7.73 & $-0.73 /-1.20 /-0.80$ \\
ABR/TB/Left & 4,000 at $100 \mathrm{~dB}$ & 12.00 & 11.73 & 11.33 & 7.27 & $-0.37 /-0.67 /-4.73$ \\
ABR/TB/Right & 4,000 at $100 \mathrm{~dB}$ & 11.00 & 10.67 & 9.87 & 6.73 & $-0.33 /-1.33 /-4.27$ \\
\hline ABR:
\end{tabular}

ABR: auditory brainstem response, AC: air conduction clicks, TB: tone burst

apy for children with SNHL.

\section{Statistical results}

The overall effect of treatment is statistically significant $(p<$ $0.05)$ for ABR click right, TB left at $1,000 \mathrm{~Hz}$ and TB left at $4,000 \mathrm{~Hz}$ (Table 8A). Although the change in threshold is statistically significant only for 3 of the 10 measurements, it is somewhat expected due to the very small sample size and some missing data within the small pool. However, among 30 possible mean change scores at the 3 follow-ups, 25 showed improvement (Table 8A). Under the null hypothesis of no treatment effect, the probability of observing at least 25 improvements out of 30 is calculated using a binomial distribution to be only 0.00016 . This is a very strong indication of the efficacy of the intervention that is not entirely captured by the individual significance tests for the threshold change scores.

The overall effect of treatment for latencies is not statistically significant for any of the measurements (Table 8B). However, among 36 possible mean change scores at the three follow-ups, 31 showed improvement (Table 8B). Under the null hypothesis of no treatment effect, the probability of observ- ing at least 31 improvements out of 36 is calculated using a binomial distribution to be only 0.000006 . This is a very strong indication of the efficacy of the intervention that is not reflected by the individual significance tests for the latency change scores.

\section{MRI with DTI outcomes}

FA is a sensitive marker of white matter integrity and myelination [18]. Decreased FA has been demonstrated in patients with SNHL $[19,20]$. No 12-month imaging data were available for 3 patients: subject 7 dropped out after the 1-month follow-up, subject 5's parents refused 12-month imaging, and subject 11 underwent bilateral cochlear implantation before his 6-month follow-up. FA changes were found in 3 of the 5 subjects with improved ABR thresholds (subject 5's parents declined 12-month follow-up imaging and subject 6 showed no change in anisotropy). Subject 1 , who did not improve on the audiologic measure, showed a positive change in anisotropy within Heschl's gyrus, although this was less robust than the changes found in the other subjects. The mean FA comparing subjects with ABR threshold improvement (responders) 
Table 5. ABR and CN VIII wave 5 latencies for responding subject 8

\begin{tabular}{|c|c|c|c|c|c|c|}
\hline \multicolumn{7}{|c|}{$\begin{array}{l}\text { A. ABR sensitivity: } A B R \text { AC anc } \\
\text { 12-month follow-up) }\end{array}$} \\
\hline Test/Ear & $\begin{array}{l}\text { Frequency } \\
(\mathrm{Hz})\end{array}$ & $\begin{array}{l}\text { Baseline } \\
\text { (dB) }\end{array}$ & $\begin{array}{c}1 \text { month } \\
\text { after } R x(d B)\end{array}$ & $\begin{array}{c}6 \text { months } \\
\text { after } R x(d B)\end{array}$ & $\begin{array}{c}1 \text { year } \\
\text { after } R x(d B)\end{array}$ & $\begin{array}{l}\text { Change from baseline }(\mathrm{dB}) \\
\qquad 1 / 6 / 12 \text { months }\end{array}$ \\
\hline ABR/AC/Left & 2,000 & 100 & 85 & 90 & 85 & $-15 /-10 /-15$ \\
\hline ABR/AC/Right & 2,000 & 20 & 20 & 20 & 20 & $0 / 0 / 0$ \\
\hline ABR/TB/Left & 500 & 95 & 95 & 95 & 90 & $0 / 0 /-5$ \\
\hline ABR/TB/Right & 500 & 25 & 25 & 25 & 25 & $0 / 0 / 0$ \\
\hline ABR/TB/Left & 1,000 & 95 & 90 & 90 & 90 & $-5 /-5 /-5$ \\
\hline ABR/TB/Right & 1,000 & 20 & 20 & 20 & 20 & 0/0/0 \\
\hline ABR/TB/Left & 2,000 & 90 & 95 & 95 & 95 & $0 / 5 / 5$ \\
\hline ABR/TB/Right & 2,000 & 20 & 20 & 20 & 20 & $0 / 0 / 0$ \\
\hline ABR/TB/Left & 4,000 & 100 & 95 & 100 & 100 & $-5 / 0 / 0$ \\
\hline ABR/TB/Right & 4,000 & 20 & 20 & 20 & 20 & $0 / 0 / 0$ \\
\hline \multicolumn{7}{|c|}{$\begin{array}{l}\text { B. Latency: } A B R \text { wave } V \text { latency (ms)-the speed/efficiency of signal transmission along the cochlear nerve (tympanometry C/C } \\
\text { at pre, and A/A at 1-, 6-, and 12-month follow-up) }\end{array}$} \\
\hline Test/Ear & Frequency $(\mathrm{Hz})$ & $\begin{array}{l}\text { Baseline } \\
\text { latency }\end{array}$ & $\begin{array}{l}1 \text { month } \\
\text { after Rx }\end{array}$ & $\begin{array}{l}6 \text { months } \\
\text { after Rx }\end{array}$ & $\begin{array}{c}1 \text { year } \\
\text { after } R x\end{array}$ & $\begin{array}{c}\text { Change from baseline } \\
1 / 6 / 12 \text { months }\end{array}$ \\
\hline ABR/AC/Left & 2,000 at $100 \mathrm{~dB}$ & 7.40 & 7.60 & 8.07 & 7.73 & $0.2 / 0.67 / 0.33$ \\
\hline ABR/AC/Right & 2,000 at $20 \mathrm{~dB}$ & 7.80 & 7.40 & 7.27 & 8.60 & $-0.4 /-0.53 / 0.80$ \\
\hline ABR/TB/Left & 500 at $95 \mathrm{~dB}$ & 8.27 & 7.40 & 7.67 & NA & $-0.87 /-0.6 / N A$ \\
\hline ABR/TB/Right & 500 at $25 \mathrm{~dB}$ & 14.53 & 12.73 & 12.20 & 13.73 & $-1.8 /-2.33 /-0.8$ \\
\hline ABR/TB/Left & 1,000 at $95 \mathrm{~dB}$ & 8.93 & 7.60 & 7.07 & NA & $-1.33 /-1.86 / \mathrm{NA}$ \\
\hline ABR/TB/Right & 1,000 at $20 \mathrm{~dB}$ & 12.67 & 11.87 & 12.07 & 11.20 & $-0.8 /-0.6 /-1.47$ \\
\hline ABR/TB/Left & 2,000 at $95 \mathrm{~dB}$ & 11.47 & 10.73 & 10.07 & 9.33 & $-0.74 /-1.4 /-2.14$ \\
\hline ABR/TB/Right & 2,000 at $20 \mathrm{~dB}$ & 10.00 & 9.40 & 9.13 & 10.07 & $-0.6 /-0.87 / 0.07$ \\
\hline ABR/TB/Left & 4,000 at $100 \mathrm{~dB}$ & 8.80 & 8.47 & 9.13 & 8.33 & $-0.33 / 0.33 /-0.43$ \\
\hline ABR/TB/Right & 4,000 at $20 \mathrm{~dB}$ & 9.80 & 8.13 & 7.80 & 8.13 & $-1.67 /-2.0 /-1.67$ \\
\hline
\end{tabular}

ABR: auditory brainstem response, $\mathrm{AC}$ : air conduction clicks, TB: tone burst

to subjects without ABR threshold improvement (non-responders) at ROI sites within Heschl's gyrus are shown in Fig. 3A. Maximal FA at ROI sites along the auditory pathways are shown in Fig. 3B.

Our study demonstrates increased mean FA primarily within the white matter of Heschl's gyrus in some patients who experienced an improvement in audiologic function following hUCB infusion, although this was not statistically significant. The data suggest that hUCB treatment can allow progressive myelination and strengthened integrity of auditory pathways in children with acquired SNHL.

\section{Discussion}

Our data demonstrate that the infusion of autologous hUCB to children with SNHL is safe. There was no evidence of infusion-related toxicity in pulmonary, hepatic, hematologic, renal or neurological organ systems. Further, autologous hUCB is feasible within the context of a children's hospital with bone marrow transplant expertise. Improvement in ABR threshold, when observed, was evident on testing at one-month post treatment and durable over the 12-month follow-up period.

Our phase 1 study evaluating the potential toxicity of autologous hUCB infusion in children with SNHL followed an uncontrolled design. Because the cochlea is post-mitotic at birth and because spontaneous repair of the cochlea has not been reported, we compared pre-treatment cochlear function to post-treatment cochlear function. Although improved structural, behavioral and functional outcomes were observed, our study is underpowered and not designed to conclude any difference with treatment. However, the observed safety of the protocol and promising pre-clinical research showing a benefit from hUCB-derived cell therapy for SNHL warrants the implementation of controlled phase 2 trials.

\section{Rationale for cell type, dosing and route}

Two major classes of progenitor cell-based therapies are commonly utilized: autologous and allogenic. We chose to use autologous hUCB for many reasons: 1) no immune barrier considerations, 2) no in vitro culture/scaling issues for au- 
Table 6. ABR and CN VIII wave 5 latencies for responding subject 5

\begin{tabular}{|c|c|c|c|c|c|c|}
\hline \multicolumn{7}{|c|}{$\begin{array}{l}\text { A. ABR sensitivity: } A B R A C \text { and } A B R \text { TB at } 500,1,000,2,000 \text {, and } 4,000 \mathrm{~Hz} \text { (tympanometry: baseline } A / B, 1 \text {-month f/u A/B, 6-month } \\
\text { f/u B/B, 12-month f/U A/B) }\end{array}$} \\
\hline Test/Ear & $\begin{array}{l}\text { Frequency } \\
\qquad(\mathrm{Hz})\end{array}$ & $\begin{array}{l}\text { Baseline } \\
\text { (dB) }\end{array}$ & $\begin{array}{l}1 \text { month } \\
\text { after } \operatorname{Rx}(\mathrm{dB})\end{array}$ & $\begin{array}{l}6 \text { months } \\
\text { after } \operatorname{Rx}(d B)\end{array}$ & $\begin{array}{l}1 \text { year } \\
\text { after } \operatorname{Rx}(\mathrm{dB})\end{array}$ & $\begin{array}{l}\text { Change from baseline }(\mathrm{dB}) \\
\qquad 1 / 6 / 12 \text { months }\end{array}$ \\
\hline ABR/AC/Left & 2,000 & 45 & 40 & 40 & 35 & $-5 /-5 /-10$ \\
\hline ABR/AC/Right & 2,000 & 55 & 40 & 45 & 45 & $-15 /-10 /-10$ \\
\hline ABR/TB/Left & 500 & 60 & 50 & 40 & 55 & $-5 /-20 /-5$ \\
\hline ABR/TB/Right & 50 & 65 & 45 & 60 & 55 & $-20 /-5 /-10$ \\
\hline ABR/TB/Left & 1,000 & 55 & 45 & 60 & 45 & $-10 / 5 /-10$ \\
\hline ABR/TB/Right & 1,000 & 50 & 45 & 35 & 45 & $-5 /-15 /-5$ \\
\hline ABR/TB/Left & 2,000 & 45 & 45 & 40 & 45 & $0 /-5 / 0$ \\
\hline ABR/TB/Right & 2,000 & 55 & 45 & 50 & 45 & $-10 /-5 /-10$ \\
\hline ABR/TB/Left & 4,000 & 50 & 40 & 35 & 40 & $-10 /-15 /-10$ \\
\hline ABR/TB/Right & 4,000 & 50 & 40 & 40 & 45 & $-10 /-10 /-5$ \\
\hline
\end{tabular}

B. Latency: $A B R$ wave $V$ latency $(\mathrm{ms})$-the speed/efficiency of signal transmission along the cochlear nerve (tympanometry: baseline A/B 1-month f/u A/B, 6-month f/u B/B, 12-month f/u A/B)

\begin{tabular}{lcccccc}
\hline \multicolumn{1}{c}{ Test/Ear } & $\begin{array}{c}\text { Frequency } \\
(\mathrm{Hz})\end{array}$ & Baseline & $\begin{array}{c}1 \text { month } \\
\text { after Rx }\end{array}$ & $\begin{array}{c}\text { 6 months } \\
\text { after Rx }\end{array}$ & $\begin{array}{c}1 \text { year } \\
\text { after Rx }\end{array}$ & $\begin{array}{c}\text { Change from baseline } \\
1 / 6 / 12 \text { months }\end{array}$ \\
\hline ABR/AC/Left & 2,000 at $80 \mathrm{~dB}$ & 6.07 & 5.60 & 5.00 & 5.13 & $-0.47 /-1.07 /-0.94$ \\
ABR/AC/Right & 2,000 at $80 \mathrm{~dB}$ & 6.60 & 5.53 & 6.00 & 5.13 & $-1.07 /-0.60 /-1.47$ \\
ABR/TB/Left & 500 at $60 \mathrm{~dB}$ & 8.60 & 8.13 & 7.87 & 8.00 & $-0.47 /-0.73 /-0.60$ \\
ABR/TB/Right & 500 at $60 \mathrm{~dB}$ & 8.60 & 7.60 & 12.73 & 7.53 & $-1.00 /+4.13 /-1.07$ \\
ABR/TB/Left & 1,000 at $50 \mathrm{~dB}$ & 8.87 & 8.40 & $\mathrm{NA}$ & 8.13 & $-0.47 / \mathrm{NA} /-0.74$ \\
ABR/TB/Right & 1,000 at $60 \mathrm{~dB}$ & 8.53 & 7.40 & 8.67 & $\mathrm{NA}$ & $-1.13 /+0.14 / \mathrm{NA}$ \\
ABR/TB/Left & 2,000 at $60 \mathrm{~dB}$ & 7.07 & 6.73 & 6.60 & 6.53 & $-0.34 /-0.47 /-0.54$ \\
ABR/TB/Right & 2,000 at $60 \mathrm{~dB}$ & 7.60 & 6.67 & 7.87 & 6.60 & $-0.93 /+0.27 /-1.0$ \\
ABR/TB/Left & 4,000 at $60 \mathrm{~dB}$ & 6.67 & 6.20 & 6.07 & $\mathrm{NA}$ & $-0.47 /-0.60 / \mathrm{NA}$ \\
ABR/TB/Right & 4,000 at $60 \mathrm{~dB}$ & 7.13 & 6.27 & 6.87 & $\mathrm{NA}$ & $-0.86 /-0.26 / \mathrm{NA}$ \\
\hline ABR:
\end{tabular}

ABR: auditory brainstem response, $\mathrm{AC}$ : air conduction clicks, TB: tone burst

tologous applications, 3) ready availability, 4) no concerns regarding uncontrolled replication as with embryonic or fetal cells, and 5) no ethical objections to cell type.

As ours is the first trial to prospectively evaluate the use of autologous hUCB infusion for acquired SNHL, appropriate cell dosing was not defined at the beginning of our study. The cell dose was increased as the study proceeded. We saw no infusion-related toxicities but did note improvement in ABR thresholds and 8th cranial nerve peak $\mathrm{V}$ latencies in some subjects receiving greater than $15 \times 10^{6} \mathrm{TNCs} / \mathrm{kg}$. Behavioral testing results (audiograms) correlated with physiologic (ABR) improvement (Fig. 2). These results provide direction for the establishment of a dose-response curve in subsequent trials.

We chose to deliver our hUCB intravenously because of the well-established safety of the administration of this cell type using this route in children with hematologic disease. In addition, a treatment effect was observed in pre-clinical trials using the intravenous delivery of hUCB-derived progenitor cell preparations. Further, the risks and potential complications of a direct surgical delivery of progenitor cells to the co- chlea were avoided.

\section{Functional outcome}

Most (5/8) subjects receiving greater than the threshold dose of $15 \times 10^{6}$ cells $/ \mathrm{kg}$ experienced a durable reduction in their ABR thresholds following hUCB treatment (Table 3). When the pre-treatment ABRs were used as a control measure, this improvement was statistically significant for the entire study population at several frequencies (Table 8A). In addition, cranial nerve 8 wave 5 latencies improved in $4 / 6$ subjects treated above threshold (Table 4-7). For properly amplified subjects receiving appropriate speech-language therapy, language development was normal following treatment (Table 9).

\section{Structural correlates to functional outcome data}

Our study included high-resolution MRI imaging with DTI sequences before and one year after hUCB treatment. We included an analysis of FA at sites along the auditory pathways. FA is a measure of white matter tract integrity, and increased FA suggests white matter tract repair. When FA measures 
Table 7. ABR and 7B CN VIII wave 5 latencies for responding subject 6

\begin{tabular}{|c|c|c|c|c|c|c|}
\hline \multicolumn{7}{|c|}{$\begin{array}{l}\text { A. ABR sensitivity: } A B R \text { AC and } A B R \text { TB at } 500,1,000 \\
\text { 6-month follow-up C/A, 12-month follow-up C/C) }\end{array}$} \\
\hline Test/Ear & $\begin{array}{l}\text { Frequency } \\
\quad(\mathrm{Hz})\end{array}$ & $\begin{array}{l}\text { Baseline } \\
\text { (dB) }\end{array}$ & $\begin{array}{l}1 \text { month } \\
\text { after } R x(d B)\end{array}$ & $\begin{array}{l}6 \text { months } \\
\text { after } \mathrm{Rx}(\mathrm{dB})\end{array}$ & $\begin{array}{l}1 \text { year } \\
\text { after } \operatorname{Rx}(\mathrm{dB})\end{array}$ & $\begin{array}{l}\text { Change from baseline }(\mathrm{dB}) \\
1 / 6 / 12 \text { months }\end{array}$ \\
\hline ABR/AC/Left & 2,000 & 40 & 35 & 40 & 30 & $-5 / 0 /-10$ \\
\hline ABR/AC/Right & 2,000 & 35 & 35 & 35 & 30 & $0 / 0 /-5$ \\
\hline ABR/TB/Left & 500 & 35 & 40 & 50 & 40 & $+5 /+15 /+5$ \\
\hline ABR/TB/Right & 500 & 45 & 45 & 50 & 45 & $0 /+5 / 0$ \\
\hline ABR/TB/Left & 1,000 & 45 & 40 & 40 & 40 & $-5 /-5 /-5$ \\
\hline ABR/TB/Right & 1,000 & 40 & 30 & 40 & 30 & $-10 / 0 /-10$ \\
\hline ABR/TB/Left & 2,000 & 45 & 35 & 40 & 35 & $-10 /-5 /-10$ \\
\hline ABR/TB/Right & 2,000 & 35 & 30 & 35 & 40 & $-5 / 0 /+5$ \\
\hline ABR/TB/Left & 4,000 & 55 & 40 & 40 & 40 & $-15 /-15 /-15$ \\
\hline ABR/TB/Right & 4,000 & 45 & 40 & 40 & 45 & $-5 /-5 / 0$ \\
\hline \multicolumn{7}{|c|}{$\begin{array}{l}\text { B. Latency: ABR wave } V \text { latency (ms)-the speed/efficiency of signal transmission along the cochlear nerve (tympanometry: } \\
\text { baseline A/A, 1-month follow-up A/A, 6-month follow-up C/A, 12-month follow-up C/C) }\end{array}$} \\
\hline Test/Ear & $\begin{array}{c}\text { Frequency } \\
(\mathrm{Hz})\end{array}$ & Baseline & $\begin{array}{l}1 \text { month } \\
\text { after Rx }\end{array}$ & $\begin{array}{l}6 \text { months } \\
\text { after Rx }\end{array}$ & $\begin{array}{c}1 \text { year } \\
\text { after Rx }\end{array}$ & $\begin{array}{c}\text { Change from baseline } \\
1 / 6 / 12 \text { months }\end{array}$ \\
\hline ABR/AC/Left & 2000 at $80 \mathrm{~dB}$ & 6.73 & 6.13 & 6.07 & 6.33 & $-0.6 /-0.66 /-0.40$ \\
\hline ABR/AC/Right & 2000 at $80 \mathrm{~dB}$ & 6.33 & 5.87 & 5.87 & 6.07 & $-0.46 /-0.46 /-0.24$ \\
\hline ABR/TB/Left & 500 at $70 \mathrm{~dB}$ & 8.80 & 8.07 & 8.40 & 8.67 & $-0.73 /-0.40 /-0.13$ \\
\hline ABR/TB/Right & 500 at $70 \mathrm{~dB}$ & 9.13 & 8.00 & 8.27 & 8.27 & $-1.13 /-0.86 /-0.86$ \\
\hline ABR/TB/Left & 1000 at $50 \mathrm{~dB}$ & 9.53 & 9.33 & NA & 9.53 & $-0.20 / \mathrm{NA} / 0$ \\
\hline ABR/TB/Right & 1000 at $50 \mathrm{~dB}$ & 9.60 & 9.13 & 9.60 & 9.87 & $-0.47 / 0 /+0.27$ \\
\hline ABR/TB/Left & 2000 at $50 \mathrm{~dB}$ & 8.73 & 8.00 & 8.47 & 8.47 & $-0.73 /-0.26 /-0.26$ \\
\hline ABR/TB/Right & 2000 at $50 \mathrm{~dB}$ & 8.33 & 7.73 & 7.80 & 8.60 & $-0.60 /-0.53 /+0.27$ \\
\hline ABR/TB/Left & 4000 at $50 \mathrm{~dB}$ & 7.80 & 7.53 & 7.67 & 8.93 & $-0.27 /-0.13 /+1.13$ \\
\hline ABR/TB/Right & 4000 at $50 \mathrm{~dB}$ & 8.33 & 7.07 & 6.93 & 8.47 & $-1.26 /-1.40 /+0.14$ \\
\hline
\end{tabular}

ABR: auditory brainstem response, $\mathrm{AC}$ : air conduction clicks, TB: tone burst

were compared between responding and nonresponding subjects (Fig. 3), a trend suggesting increased FA along these pathways in responding subjects was identified. The improvement in FA was most pronounced in the primary auditory cortex (Heschl's gyrus). Taken together, our phase 1 data suggest that repair of the cochlea (ABR), spiral ganglion and the entire auditory pathway may be possible after hUCB treatment.

\section{Potential mechanisms of action}

Cochlear hair cell regeneration could be caused by direct interaction with hUCB cells, as well as by local or systemic paracrine effects caused by hUCB infusion. The cochlea is known to have resident macrophages, and macrophages can be recruited to the cochlea from circulating monocytes to damaged and dying inner hair cells $[21,22]$. A subset of cochlear support cells have been characterized as "stem-like" progenitor cells [23]. Recent pre-clinical studies have demonstrated the migration of human mesenchymal stem cells to the cochlea of congenitally deaf albino pigs and immunocompromised mice deafened by kanamycin [24,25]. In the mouse model, the mesenchymal cells were found to have fused with cochlear support cells, and hair cell regeneration was felt to be secondary to a local paracrine effect. In the pig model, umbilical cord mesenchymal stem cells were identified within the cochlea, and the treated animals' ABRs showed improvement.

Following intravenous infusion, the majority of hUCB cells do not cross the blood-brain barrier [10,26]. Intravenous delivery of mesenchymal stem cells is known to alter circulating cytokines and macrophage cell phenotype. While it is possible that some hUCB cells may reach the cochlea and directly induce repair [24], it is also possible that this immune modifying treatment may allow the differentiation of resident cochlear cells into new hair cells through a systemic paracrine effect [27]. Cochlear progenitor cells may be induced to differentiate into hair cells by local or systemic paracrine effects, direct contact with hUCB cells, or a combination of these processes. Repair of the spiral ganglion and the cells contributing to the auditory pathways through similar mechanisms is also possible [8-14].

Treatments to induce hearing recovery using gene therapy 
Table 8. Statistical analysis of study ABR and cranial nerve 8 wave 5 latencies

\begin{tabular}{|c|c|c|c|c|c|}
\hline \multicolumn{6}{|c|}{$\begin{array}{l}\text { A. Within-subject ANOVA results for the change in } 5 \text { ABR threshold scores for the left and right ears along with the mean change } \\
\text { scores at each of three follow-up times. }\end{array}$} \\
\hline Test/Ear & $\begin{array}{l}\text { Frequency } \\
\qquad(\mathrm{Hz})\end{array}$ & $\begin{array}{c}\text { Mean change } \\
1 \text { month after Rx }(\mathrm{dB}) \& \\
p \text {-values }\end{array}$ & $\begin{array}{c}\text { Mean change } \\
6 \text { months after } \operatorname{Rx}(\mathrm{dB}) \& \\
\text { p-values }\end{array}$ & $\begin{array}{c}\text { Mean change } \\
1 \text { year after } \mathrm{Rx}(\mathrm{dB}) \& \\
\text { p-values }\end{array}$ & $\begin{array}{l}\text { p-values for overall } \\
\text { effect of treatment } \\
\text { over time }\end{array}$ \\
\hline ABR/AC/Left & 2,000 & $-4.5000(0.0554)$ & $-4.6814(0.0554)$ & $-3.0759(0.1103)$ & 0.2163 \\
\hline ABR/AC/Right & 2,000 & $-7.7778(0.0165)$ & $-8.8889(0.0070)$ & $-5.0000(0.1103)$ & 0.0322 \\
\hline ABR/TB/Left & 500 & $-1.8937(0.4440)$ & $-2.9642(0.2562)$ & $-2.3392(0.3675)$ & 0.6773 \\
\hline ABR/TB/Right & 500 & $-5.0000(0.1955)$ & $-5.0574(0.2092)$ & $-4.4324(0.2691)$ & 0.4983 \\
\hline ABR/TB/Left & 1,000 & $-3.5000(0.0516)$ & $-5.1978(0.0102)$ & $-4.5728(0.0217)$ & 0.0404 \\
\hline ABR/TB/Right & 1,000 & $-3.0000(0.4769)$ & $-1.2059(0.7824)$ & $1.5719(0.7190)$ & 0.7495 \\
\hline ABR/TB/Left & 2,000 & $-1.0000(0.7039)$ & $-1.4484(0.6137)$ & $1.0516(0.7136)$ & 0.8226 \\
\hline ABR/TB/Right & 2,000 & $-1.9279(0.5318)$ & $0.2943(0.9237)$ & $3.6276(0.2442)$ & 0.3493 \\
\hline ABR/TB/Left & 4,000 & $-6.6667(0.0021)$ & $-5.4719(0.0119)$ & $-6.0969(0.0058)$ & 0.0081 \\
\hline ABR/TB/Right & 4,000 & $-4.3750(0.2584)$ & $-3.7500(0.3307)$ & $2.5000(0.5140)$ & 0.2481 \\
\hline \multicolumn{6}{|c|}{$\begin{array}{l}\text { B. Within-subject ANOVA results for change in } 6 \text { latency scores for left and right ears along with the mean change scores at } \\
\text { each of three follow-up times. }\end{array}$} \\
\hline Test/Ear & $\begin{array}{l}\text { Frequency } \\
\qquad(\mathrm{Hz})\end{array}$ & $\begin{array}{c}\text { Mean change } \\
1 \text { month after Rx }(\mathrm{ms}) \& \\
\text { p-values }\end{array}$ & $\begin{array}{c}\text { Mean change } \\
6 \text { months after Rx (ms) \& } \\
\text { p-values }\end{array}$ & $\begin{array}{c}\text { Mean change } \\
1 \text { year after Rx (ms) \& } \\
\text { p-values }\end{array}$ & $\begin{array}{l}\text { p-values for overall } \\
\text { effect of treatment } \\
\text { over time }\end{array}$ \\
\hline I/Left & 2,000 & $0.05775(0.7790)$ & $0.2176(0.1980)$ & $-0.05711(0.1715)$ & 0.3926 \\
\hline III/Left & 2,000 & $-0.1529(0.2872)$ & $-0.01496(0.8894)$ & $-0.1452(0.2201)$ & 0.4412 \\
\hline V/Left & 500 & $-0.3832(0.0618)$ & $-0.1911(0.2333)$ & $-0.3991(0.0299)$ & 0.0999 \\
\hline I-III/Left & 500 & $0.3405(0.4555)$ & $-0.06258(0.8655)$ & $-0.3929(0.3336)$ & 0.4829 \\
\hline III-V/Left & 1,000 & $-1.0222(0.1578)$ & $-0.7122(0.2195)$ & $-0.2039(0.7424)$ & 0.4222 \\
\hline I-V/Left & 1,000 & $-0.3250(0.3670)$ & $-0.5089(0.0890)$ & $-0.3569(0.2633)$ & 0.3628 \\
\hline I/Right & 2,000 & $0.01866(0.8069)$ & $0.09486(0.1830)$ & $-0.00071(0.9921)$ & 0.4923 \\
\hline III/Right & 2,000 & $-0.2060(0.0861)$ & $-0.2103(0.0558)$ & $-0.1967(0.0796)$ & 0.1494 \\
\hline V/Right & 4,000 & $-0.7684(0.0227)$ & $-0.4232(0.1575)$ & $-0.3028(0.3402)$ & 0.1277 \\
\hline I-III/Right & - & $-0.1795(0.0936)$ & $-0.2295(0.0253)$ & $-0.1489(0.1602)$ & 0.1194 \\
\hline III-V/Right & - & $-0.6369(0.0489)$ & $-0.2610(0.3637)$ & $-0.1476(0.6312)$ & 0.2350 \\
\hline I-V/Right & - & $-0.8033(0.0201)$ & $-0.4910(0.1109)$ & $-0.3042(0.3482)$ & 0.1056 \\
\hline
\end{tabular}

ANOVA: analysis of variance, ABR: auditory brainstem response, AC: air conduction clicks, TB, tone burst

Table 9. Auditory verbal speech-language testing results (Preschool Language Scale, 4th Edition, Pearson, 2002)

\begin{tabular}{|c|c|c|c|c|c|}
\hline Subject & $\begin{array}{c}\text { PLS 4, standard score } \\
\text { (baseline) }\end{array}$ & $\begin{array}{l}\text { PLS 4, standard score } \\
\text { (6 months) }\end{array}$ & $\begin{array}{l}\text { PLS 4, standard score } \\
\text { (12 months) }\end{array}$ & $\begin{array}{c}\text { Consistent } \\
\text { amplification }\end{array}$ & Home language \\
\hline 1 & 126 & 108 & 115 & + & English \\
\hline 2 & 86 & 97 & 123 & + & English \\
\hline 3 & 99 & 97 & 123 & + & English \\
\hline 4 & 50 & 50 & 50 & - & English \\
\hline 5 & 61 & 62 & 71 & + & English \\
\hline 6 & 111 & 113 & 122 & + & English \\
\hline 7 & 106 & NT & NT & + & English \\
\hline 8 & 114 & 116 & 115 & + & English/Korean \\
\hline 9 & 84 & 93 & 108 & + & English/ASL \\
\hline 10 & 80 & 97 & NT & + & English \\
\hline 11 & 69 & NT & NT & + & English \\
\hline
\end{tabular}

Subject 7 dropped out of the study, and Subject 11 underwent bilateral cochlear implantation after the 1-month follow-up. Subject 10 refused testing at 12-month follow-up. PLS: Preschool Language Score, ASL: American Sign Language 


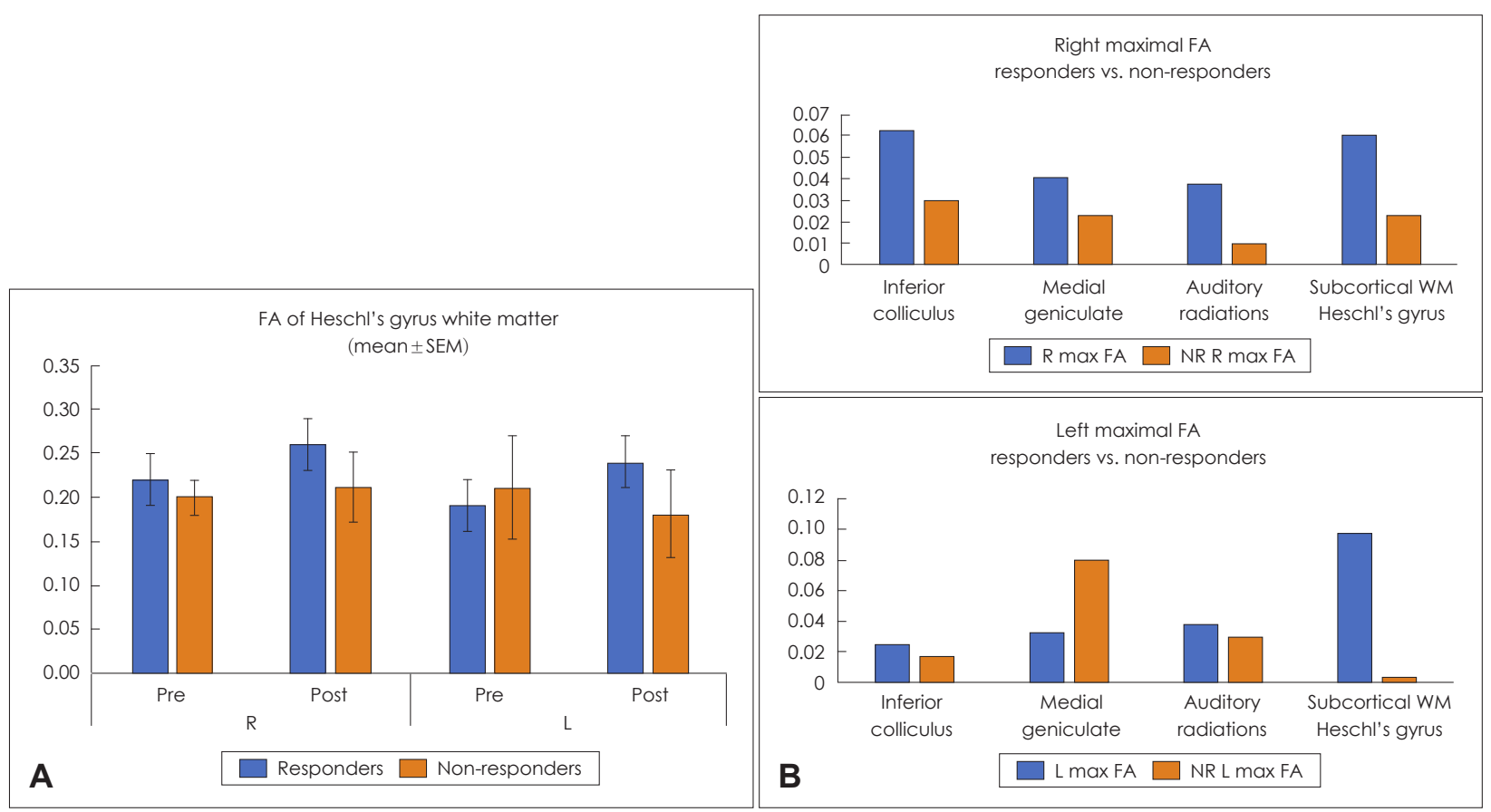

Fig. 3. A: Graphic representation of mean FA in the region of interest of Heschl's gyrus white matter comparing responding and non-responding study subjects before (pre) and after (post) hUCB treatment. B: Graphic representation of maximal FA at selected sites along the auditory pathways comparing responding $(R)$ and non-responding $(N R)$ study subjects following hUCB treatment. FA: fractional anisotropy, hUCB: human umbilical cord blood, SEM: standard error of the mean.

or the direct delivery of stem cells, viruses, or small molecules directly into the cochlea are currently under investigation [2730]. In addition to the potential surgical morbidity, these approaches focus narrowly on cochlear repair and do not address the associated pathways necessary for hearing and language. These direct delivery approaches might be enhanced by hUCB treatment, which appears to target the cochlea, the spiral ganglion and the associated pathways for hearing.

In conclusion, our phase 1 open label study fulfilled the objective of evaluating the safety of intravenous autologous hUCB mononuclear fraction infusion for the treatment of acquired SNHL. We exceeded the minimal $6 \times 10^{6} \mathrm{TNC} / \mathrm{kg}$ in all patients, and the per kilo cell dose was increased throughout the trial. Functional and associated structural improvements were observed in several subjects receiving higher perkilogram doses of cord blood cells. The range in age of the responding subjects at treatment ( 9 months to 3 years 7 months) suggests a long window of opportunity for effective treatment. Because of the limited sample size, our study is underpowered and not designed to make conclusions on differences due to treatment. ABR thresholds would not be expected to spontaneously improve in this patient population. The observed safety of the protocol and promising clinical data suggest a benefit from cord blood-derived cell therapy for acquired SNHL. The data warrant the implementation of larger controlled phase $2 / 3$ trials of this intervention in children with acquired SNHL.

\section{Acknowledgments}

This study was supported by a grant from Cord Blood Registry ${ }^{\circledR}$ $(\mathrm{CBR} \Re)$. Additional support was provided by Wayne Densch Charities.

\section{Conflicts of interest}

The authors have no financial conflicts of interest.

\section{REFERENCES}

1) Lin FR, Niparko JK, Ferrucci L. Hearing loss prevalence in the United States. Arch Intern Med 2011;171:1851-2.

2) Mehra S, Eavey RD, Keamy DG Jr. The epidemiology of hearing impairment in the United States: newborns, children, and adolescents. Otolaryngol Head Neck Surg 2009;140:461-72.

3) Shibata SB, Sheearer AE, Smith RJH. Genetic sensorinerual hearing loss. In: Flint PW, Haughey BH, Lund VJ, Niparko JK, Robbins KT, Thomas JR, et al., editors. Cummings Otolaryngology—Head and Neck Surgery. 6th ed. Philladepphia, PA: Saunders, an imprint of Elsevier;2014. p.2285-300.

4) Canalis RF, Lambert PR. The ear: comprehensive otology. 1st ed. Philadelphia (PA): Lippincott Williams and Wilkins;2000.

5) Smith RJ, Bale JF Jr, White KR. Sensorineural hearing loss in children. Lancet 2005;365:879-90.

6) Prockop DJ. Marrow stromal cells as stem cells for nonhematopoietic tissues. Science 1997;276:71-4

7) Cox CS Jr, Baumgartner JE, Harting MT, Worth LL, Walker PA, Shah SK, et al. Autologous bone marrow mononuclear cell therapy for severe traumatic brain injury in children. Neurosurgery 2011;68: 588-600.

8) Vahidy FS, Rahbar MH, Zhu H, Rowan PJ, Bambhroliya AB, Savitz SI. Systematic review and meta-analysis of bone marrow-derived 
mononuclear cells in animal models of ischemic stroke. Stroke 2016; 47:1632-9.

9) Savitz SI, Misra V, Kasam M, Juneja H, Cox CS Jr, Alderman S, et al. Intravenous autologous bone marrow mononuclear cells for ischemic stroke. Ann Neurol 2011;70:59-69.

10) White SV, Czisch CE, Han MH, Plant CD, Harvey AR, Plant GW. Intravenous transplantation of mesenchymal progenitors distribute solely to the lungs and improve outcomes in cervical spinal cord injury. Stem Cells 2016;34:1812-25.

11) van Velthoven CT, Dzietko M, Wendland MF, Derugin N, Faustino J, Heijnen CJ, et al. Mesenchymal stem cells attenuate MRI-identifiable injury, protect white matter, and improve long-term functional outcomes after neonatal focal stroke in rats. J Neurosci Res 2017;95: 1225-36.

12) van Velthoven CT, Sheldon RA, Kavelaars A, Derugin N, Vexler ZS, Willemen HL, et al. Mesenchymal stem cell transplantation attenuates brain injury after neonatal stroke. Stroke 2013;44:1426-32.

13) Revoltella RP, Papini S, Rosellini A, Michelini M, Franceschini V, Ciorba A, et al. Cochlear repair by transplantation of human cord blood CD133+ cells to nod-scid mice made deaf with kanamycin and noise. Cell Transplant 2008;17:665-78.

14) Choi MY, Yeo SW, Park KH. Hearing restoration in a deaf animal model with intravenous transplantation of mesenchymal stem cells derived from human umbilical cord blood. Biochem Biophys Res Commun 2012;427:629-36.

15) Da Costa V, O’Grady G, Jackson L, Kaylie D, Raynor E. Improvements in sensorineural hearing loss after cord blood transplant in patients with mucopolysaccharidosis. Arch Otolaryngol Head Neck Surg 2012;138:1071-6.

16) Zimmermann IL, Steiner VG, Pond E. Preschool Language Scale, 4th edition (PLS-4). London, UK: Pearson;2002.

17) Kurioka T, Matsunobu T, Niwa K, Tamura A, Satoh Y, Shiotani A. Activated protein $\mathrm{C}$ rescues the cochlea from noise-induced hearing loss. Brain Res 2014;1583:201-10.

18) Mukherjee P, Miller JH, Shimony JS, Philip JV, Nehra D, Snyder AZ, et al. Diffusion-tensor MR imaging of gray and white matter development during normal human brain maturation. AJNR Am J Neuroradiol 2002;23:1445-56.

19) Huang L, Zheng W, Wu C, Wei X, Wu X, Wang Y, et al. Diffusion tensor imaging of the auditory neural pathway for clinical outcome of cochlear implantation in pediatric congenital sensorineural hearing loss patients. PLoS One 2015;10:e0140643.

20) Lin Y, Wang J, Wu C, Wai Y, Yu J, Ng S. Diffusion tensor imaging of the auditory pathway in sensorineural hearing loss: changes in radial diffusivity and diffusion anisotropy. J Magn Reson Imaging 2008; 28:598-603.

21) Liu W, Molnar M, Garnham C, Benav H, Rask-Andersen H. Macrophages in the human cochlea: saviors or predators-a study using super-resolution immunohistochemistry. Front Immunol 2018;9:223.

22) Peyvandi AA, Roozbahany NA, Peyvandi H, Abbaszadeh HA, Majdinasab N, Faridan M, et al. Critical role of SDF-1/CXCR4 signaling pathway in stem cell homing in the deafened rat cochlea after acoustic trauma. Neural Regen Res 2018;13:154-60.

23) McLean WJ, McLean DT, Eatock RA, Edge AS. Distinct capacity for differentiation to inner ear cell types by progenitor cells of the cochlea and vestibular organs. Development 2016;143:4381-93.

24) Bettini S, Franceschini V, Astolfi L, Simoni E, Mazzanti B, Martini A, et al. Human mesenchymal stromal cell therapy for damaged cochlea repair in nod-scid mice deafened with kanamycin. Cytotherapy 2018;20:189-203.

25) Ma Y, Guo W, Yi H, Ren L, Zhao L, Zhang Y, et al. Transplantation of human umbilical cord mesenchymal stem cells in cochlea to repair sensorineural hearing. Am J Transl Res 2016;8:5235-45.

26) Fischer UM, Harting MT, Jimenez F, Monzon-Posadas WO, Xue H, Savitz SI, et al. Pulmonary passage is a major obstacle for intravenous stem cell delivery: the pulmonary first-pass effect. Stem Cells Dev 2009;18:683-92.

27) Simoni E, Orsini G, Chicca M, Bettini S, Franceschini V, Martini A, et al. Regenerative medicine in hearing recovery. Cytotherapy 2017; 19:909-15.

28) Diensthuber M, Stöver T. [Strategies for a regenerative therapy of hearing loss. German version]. HNO 2018;66:179-87.

29) Kesser BW, Lalwani AK. Gene therapy and stem cell transplantation: strategies for hearing restoration. Adv Otorhinolaryngol 2009; 66:64-86.

30) Ralli M, Rolesi R, Anzivino R, Turchetta R, Fetoni AR. Acquired sensorineural hearing loss in children: current research and therapeutic perspectives. Acta Otorhinolaryngol Ital 2017;37:500-8. 